\title{
ASSOCIATION OF ANTI-DOUBLE STRANDED DNA ANTIBODIES, C-REACTIVE PROTEIN, AND ERYTHROCYTE SEDIMENTATION RATE FROM PATIENTS WITH SYSTEMIC LUPUS ERYTHEMATOSUS IN TAMIL NADU
}

\author{
NATESAN MANIKANDAN ${ }^{1}$, MARIMUTHU RAGAVAN RAMESHKUMAR ${ }^{1}$, RAJESHWARI $^{2}$, \\ NARASINGAM ARUNAGIRINATHAN ${ }^{1 *}$
}

${ }^{1}$ Department of Microbiology and Biotechnology, Presidency College, Chennai, Tamil Nadu, India. ${ }^{2}$ Department of Rheumatology, Rajiv Gandhi Government General Hospital, Chennai, Tamil Nadu, India. Email: n_arunagiri@yahoo.co.in

Received: 28 July 2017, Revised and Accepted: 11 October 2017

\section{ABSTRACT}

Objective: To determine the serum levels of anti-double stranded DNA (anti-dsDNA) antibodies, serum C-reactive protein (CRP), and erythrocyte sedimentation rate (ESR) in patients with systemic lupus erythematosus (SLE) from Tamil Nadu, and elucidate their correlation level.

Methods: Blood samples were collected from 100 SLE patients (mean age 39 years) attended to the Rheumatology Care Centre, Rajiv Gandhi Government General Hospital, Chennai. Anti-dsDNA antibodies IgG in SLE patients were analyzed by Enzyme-linked Immunosorbent Assay, and CRP was measured by turbidimetry. ESR was measured by Westergren method.

Results: In a total of 100 SLE patients, 72 cases were positive for anti-dsDNA antibody. The mean level of anti-dsDNA antibodies in 72 SLE patients was $102 \mathrm{IU} / \mathrm{ml}$. Among the 100 SLE cases, 92 cases (92\%) had elevated levels of CRP and their mean level was $11 \pm 4 \mathrm{mg} / \mathrm{L}$. The mean ESR levels were high in SLE patients ( $56 \pm 20 \mathrm{~mm} / \mathrm{hr})$. Significant association of anti-dsDNA antibodies with ESR $(r=0.357 ; p<0.001)$ and CRP $(r=0.81 ; p=0.023)$ was found.

Conclusion: Anti-dsDNA antibodies had a significant association with CRP and ESR. The result of our study suggests an association of anti-dsDNA antibodies with ESR and CRP and was linked with SLE disease progression.

Keywords: Anti-double stranded DNA antibody, C-reactive protein, Erythrocyte sedimentation rate, Systemic lupus erythematosus.

(c) 2018 The Authors. Published by Innovare Academic Sciences Pvt Ltd. This is an open access article under the CC BY license (http://creativecommons. org/licenses/by/4. 0/) DOI: http://dx.doi.org/10.22159/ajpcr.2018.v11i1.21670

\section{INTRODUCTION}

Systemic lupus erythematosus (SLE) is a complex, systemic autoimmune disease in which the immune system produces numerous antibodies to nuclear antigen fragments [1]. Deposition of various antigen-antibody complexes from the different filter organs of the human body causes extensive inflammation and tissue damage [2,3]. The definite causes of SLE are unknown but are associated with genetical, environmental, and hormonal factors [4-6]. SLE commonly affects skin, joints, kidneys, brain, lungs, heart, and blood [7]. SLE is more prevalent in Asians, Afro-Americans, Afro-Caribbeans, and Hispanic Americans. Anti-double stranded DNA (dsDNA) antibodies are one of the immunological markers for diagnosis of SLE [8]. C-reactive protein (CRP) is an acute phase protein and it levels were raised when an inflammation occurs in SLE patients. Erythrocyte sedimentation rate (ESR) is an inflammatory marker for SLE disease activity [9]. The present study was aimed to find out the serum levels of anti-dsDNA) antibodies IgG, CRP, and ESR in SLE patients from Tamil $\mathrm{Nadu}$, and to elucidate their correlation level.

\section{METHODS}

\section{Study population}

The present study included 100 SLE patients. Patients were selected from outpatient wards of Rheumatology Department, Government General Hospital, Chennai, Tamil Nadu, and Arthritis and Rheumatism Care Centre, Chennai. SLE samples were collected from patients fulfilled at least four criteria of the American College of Rheumatology. Demographic characteristics of the patients were evaluated and recorded at the time of blood collection. This study was approved by the Ethical Committee of Madras Medical College and Hospital, Chennai, Tamil Nadu, and informed written consent was obtained from each participant.

\section{Sample collection}

Venous blood ( $3 \mathrm{ml}$ ) samples were collected from patients with SLE. Serum was separated and stored immediately in aliquots at $-20^{\circ} \mathrm{C}$ for further use.

\section{Determination of anti-dsDNA antibodies in SLE patients}

Anti-dsDNA antibodies were shown to play a role in SLE pathogenesis and particularly kidney damage. They have been claimed to be a serological marker for SLE. Anti-dsDNA antibodies were detected by Enzyme-linked Immune Sorbent Assay, in accordance with the manufacturer's instructions (Orgentec, Germany).

\section{CRP measurement}

Serum CRP causes agglutination of the latex particles coated with antihuman CRP. The agglutination of the latex particles is proportional to the CRP concentration and was measured by turbidimetry. The CRP kit was obtained from Biosystems, Spain. Detection limit of the test was $1.0 \mathrm{mg} / \mathrm{L}$, (Reference values: Up to $6 \mathrm{mg} / \mathrm{L}$ ).

\section{Analysis of ESR}

ESR values of blood samples collected from SLE patients were measured using Westergren method. The upper level of the red cell column from the standard Westergren tube was read at the end of 1 hour. Results were noted in four categories: <25 (normal), 25-50 (mild elevation), 51-75 (moderate elevation), and >75 (marked elevation) $\mathrm{mm} / \mathrm{h}$. 
Statistical analysis

Statistical analysis was carried out by Statistical Package for Social Sciences (SPSS) Association between anti-dsDNA antibodies and CRP or ESR was analyzed by Pearson's correlation test. Quantitative measures were presented as mean \pm SD. $P<0.05$ was considered as statistically significant.

\section{RESULTS}

A total of 100 SLE patients ( 94 females and 4 males) with age ranging between 20 and 67 years were analyzed. The mean age of the SLE patients included in this study was 39 years. Age wise distributions of SLE patients were given in Fig. 1. Maximum number of SLE cases (34\%) was found in age group 21-30 years.

In a total of 100 SLE patients, 72 cases were positive for anti-dsDNA antibody. Anti-dsDNA antibodies mean levels were $102 \mathrm{IU} / \mathrm{ml}$. Among the 100 SLE cases, 92 cases (92\%) had elevated levels of CRP, and their mean level in SLE patients was $11 \pm 4 \mathrm{mg} / \mathrm{L}$. The mean ESR level of SLE patients was $56 \pm 20 \mathrm{~mm} / \mathrm{h}$. Of 100 SLE patients, $3 \%$ patients showed normal range of ESR, while $97 \%$ patients showed elevated levels.

In this study, significant association of anti-dsDNA antibodies with ESR ( $r=0.357$; $p<0.001$ ) (Fig. 2) and CRP ( $r=0.81 ; p=0.023$ ) (Fig. 3) was found. Furthermore, negative association was obtained between

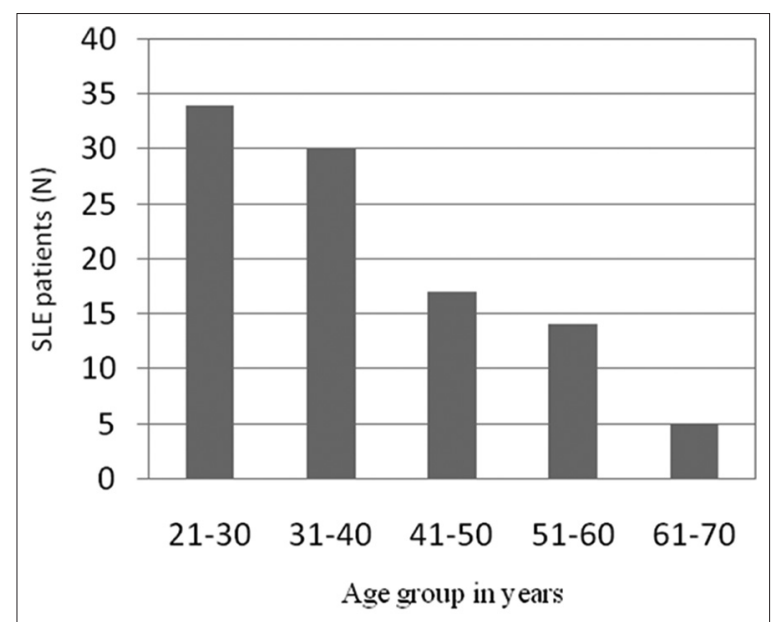

Fig. 1: Age wise distribution of systemic lupus erythematosus patients from Tamil Nadu

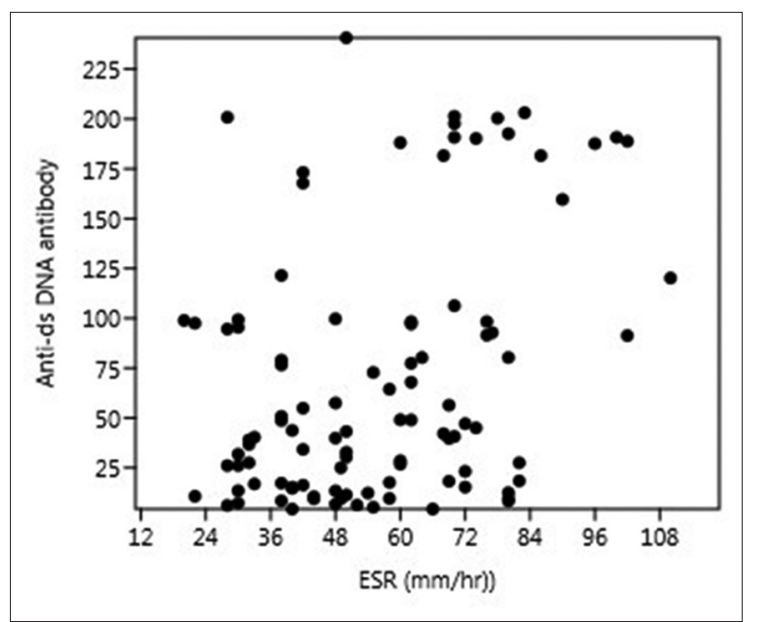

Fig. 2: Association between anti-double stranded DNA antibody and erythrocyte sedimentation rate levels among systemic lupus erythematosus patients age and anti-dsDNA antibody levels ( $\mathrm{r}=-0.11 ; \mathrm{p}=0.2)$. In our study, ESR levels were correlated positively with CRP levels $(r=0.07 ; p=0.4$ ) (Fig. 4).

\section{DISCUSSION}

In the present study, association of anti-dsDNA antibodies with CRP and ESR was analyzed in 100 patients with SLE. More females (96) were affected with SLE when compared to males (4). The female to male ratio of 24:1 is found among SLE cases in this study. Other studies also have reported a female preponderance of SLE. Malaviya et al., 1997 [10] reported a female to male ratio of 8:1 among SLE cases. Kumar, 2002 [6] reported that SLE affects predominantly women in their reproductive years and a sex ratio (F/M) of 11:1 among SLE cases in his study.

Anti-dsDNA antibody is a crucial biomarker for diagnosis of SLE. In our study, $72 \%$ of patients showed high anti-dsDNA antibody levels. Our results have confirmed the findings of Hegazy et al., 2012, [8] who have reported that $62.1 \%$ of SLE patients were anti-dsDNA positives. Habib et al., 2013 [11] also documented that $64 \%$ of SLE patients were positive for anti-dsDNA antibodies.

The results of this study showed an elevated level of ESR in patients with SLE with a mean ESR level of $56 \pm 20 \mathrm{~mm} / \mathrm{h}$. These results were

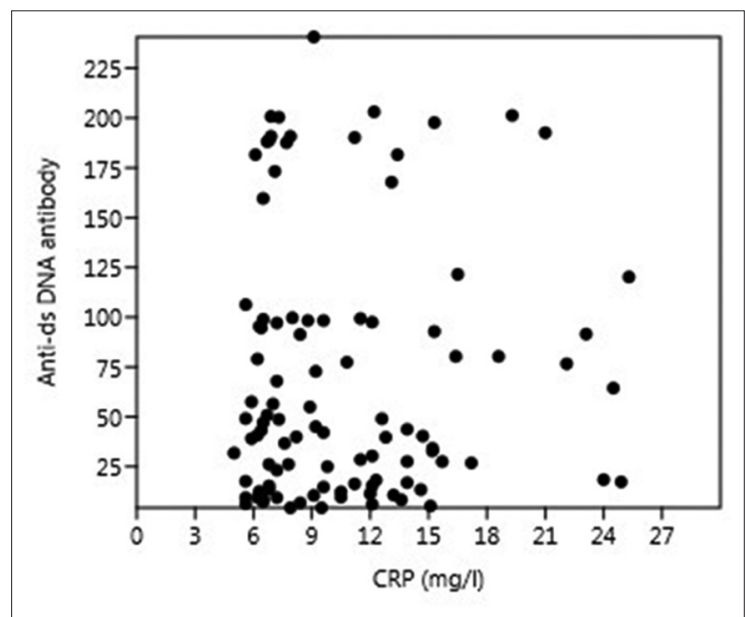

Fig. 3: Association between anti-double stranded DNA antibody and C-reactive protein levels among systemic lupus erythematosus patients

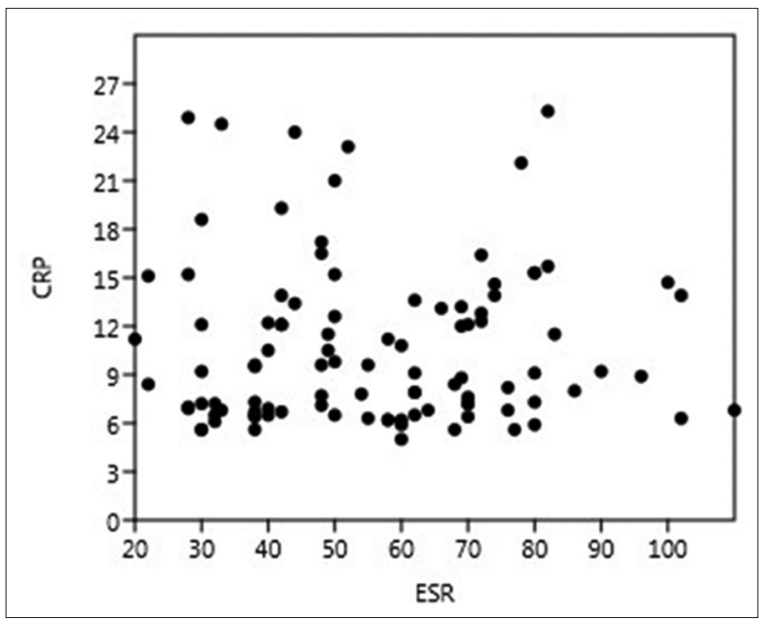

Fig. 4: Association between anti-double stranded DNA antibody and C-reactive protein levels in systemic lupus erythematosus patients 
in agreement with those of Shah et al., 2013 [12] who reported that the mean level of ESR was $49.43 \pm 24.50$.

In this study, we found $92 \%$ SLE patients had high CRP levels. Our results were differing from Pradhan et al., 2013 [4] who found only 36.4\% of elevated CRP levels. Whereas Mok et al., 2013 [13] have reported that $77 \%$ of SLE patients had high CRP level. Anti-dsDNA antibodies were significantly associated with CRP and ESR in this study. Our results were similar to that of Gheita et al., 2012 [14] who also reported that CRP levels were significantly higher in anti-dsDNA positive SLE patients. ESR elevation was more common in our study population. Elevated levels of ESR were significantly associated with anti-dsDNA. Witte et al., 1998 [15] also reported an association of anti-dsDNA antibodies with elevated levels of ESR in their study population.

The result of our study suggests an association of anti-dsDNA antibodies with ESR and CRP and was linked with SLE disease progression.

\section{REFERENCES}

1. Walport MJ. Lupus, DNase and defective disposal of cellular debris. Nat Genet 2000;25:135-6.

2. Keerthana PC, Anila KN. Carbamazepine-induced SLE-A rare and serious ADR. Int J Pharm Pharm Sci 2017;9:319-20.

3. Ronnblom L, Alm GV. Systemic lupus erythematosus and the Type I interferon system. Arthritis Res Ther 2003;5:68-75.

4. Pradhan V, Rajadhyaksha A, Patwardhan J, Surve P. High sensitivity C-reactive protein (hsCRP): Association with clinical subsets in systemic lupus erythematosus (SLE) patients from Western India. Indian J Rheumatol 2013;8:65-7.

5. Goodnow CC. Multistep pathogenesis of autoimmune disease. Cell
2007; 130:25-35

6. Kumar A. Indian guidelines on the management of SLE. J Indian Rheumatol Assoc 2002;10:80-96.

7. Rahman A, Isenberg DA. Review article: Systemic lupus erythematosus. N Engl J Med 2008;358:929-39.

8. Hegazy A, Barakat AF, Gayyar E, Arafa LF. Prevalence and clinical significance of anti-C1q antibodies in cutaneous and systemic lupus erythematosus. Egypt J Med Hum Genet 2012;13:167-71.

9. Keenan RT, Swearingen CJ, Yazici Y. Erythrocyte sedimentation rate and C-reactive protein levels are poorly correlated with clinical measures of disease activity in rheumatoid arthritis, systemic lupus erythematosus and osteoarthritis patients. Clin Exp Rheumatol 2008;26:814-9.

10. Malaviya AN, Chandrasekaran AN, Kumar A, Shamar PN. Systemic lupus erythematosus in India. Lupus 1997;6:690-700.

11. Habib HM, Arafat WR, Marie MA, Eissa AA. Pulmonary involvement in early systemic lupus erythematosus. Egypt Rheumatol 2013;35:225-31.

12. Shah D, Sah S, Wanchu A, Wu MX, Bhatnagar A. Altered redox state and apoptosis in the pathogenesis of systemic lupus erythematosus. Immunobiology 2013;218:620-7.

13. Mok CC, Birmingham DJ, Ho LY, Herbert LA, Rovin BH. High sensitivity C-reactive protein, disease activity and cardiovascular risk factors in systemic lupus erythematosus. Arthritis Care Res 2013;65:441-7.

14. Gheita TA, El-Gazzar II, Askalany G, El-Fishawy HS, El-Faramawy A. High sensitivity C-reactive protein (hs-CRP) in systemic lupus erythematosus without cardiac involvement; Relation to disease activity, damage and intima-media thickness. Egypt Rheumatol 2012;34:147-52

15. Witte T, Hartung K, Matthias T, Sachse C, Fricke M, Deicher H. Association of IgA anti-ds DNA antibodies with vasculities and disease activity in systemic lupus erythematosus. SLE study group. Rheumatol Int 1998;18:63-9. 